\title{
PENGARUH KETERAMPILAN DASAR MENGAJAR GURU TERHADAP HASIL BELAJAR FISIKA
}

\author{
Fanie Ryant Syafitri \\ Jurusan Teknik Mesin Universitas Trunajaya Bontang \\ fanieryant@yahoo.com
}

\begin{abstract}
ABSTRAK
Penelitian ini bertujuan untuk mengetahui pengaruh keterampilan dasar mengajar guru terhadap hasil belajar pelajaran fisika pada materi cahaya di kelas VIII SMP Negeri 1 Bontang. Sampel penelitian ini adalah siswa kelas VIll-A dan VIIl-B yang berjumiah 45 siswa. Jenis penelitian yang digunakan adalah penelitian kuantitatif dengan metode survey explanatory. Untuk mengukur keterampilan dasar mengajar guru dan hasil belajar siswa, teknik yang digunakan dalam pengumpulan data adalah angket dan tes tertulis. Data yang terkumpul kemudian dihubungkan dengan menggunakan uji regresi linear sederhana. Hasil penelitian menunjukkan bahwa hasil belajar siswa dengan rata rata nilai sebesar 77,22 dan keterampilan dasar mengajar guru termasuk dalam kriteria tinggi, yaitu sebesar 71\%. Dari hasil analisis regresi linear sederhana dengan bantuan program SPSS 20 didapatkan persamaan $\mathrm{Y}=17,241+0,778 \mathrm{X}$. Uji $\mathrm{F}$ diperoleh nilai $\mathrm{F}_{\text {hitung }}=56,017$ dengan signifikansi $0,000<0,05$ sehingga $\mathrm{H}_{\mathrm{a}}$ diterima. Secara parsial (uji $\mathrm{t}$ ) diperoleh $\mathrm{t}_{\text {hitung }} 4,067$ (pada taraf signifikansi 5\%) sehingga $\mathrm{H}_{\mathrm{a}}$ diterima. Secara parsial terdapat pengaruh yang signifikan antara persepsi siswa tentang keterampilan dasar mengajar guru terhadap hasil belajar fisika pada materi cahaya di kelas VII SMP Negeri 1 Bontang.
\end{abstract}

Kata kunci : Keterampilan dasar mengajar guru, hasil belajar dan siswa SMP

\section{ABSTRACT}

This study aims to determine the effect of basic teaching skills of teacher toward the learning outcomes of physics lessons on light material in class VII SMP Negeri 1 Bontang. The sample of this research was 45 students of class VIll-A and VIIl-B. The type of research used is quantitative research with survey explanatory methods. To measure the basic teaching skills of teachers and student learning outcomes, the techniques used in data collection were questionnaires and written tests. The all data which collected then processed using a simple linear regression test. The results showed that student learning outcomes with an average value of 77.22 and basic teaching skills of teachers were included in the high criteria, about 71\%. From the results of simple linear regression analysis with the help of the SPSS 20 program, the equation $Y=17.241+0.778 X$ is obtained. The $F$ test obtained $F_{\text {count }}$ value $=56.017$ with a significance of $0.000<0.05$ so that $H_{a}$ is accepted. Partially (t test) obtained tcount 4.067 (at the 5\% significance level) so that $H_{a}$ was accepted. Partially there is a significant influence between students' perceptions of the basic skills of teaching teachers on learning outcomes of physics on light material in class VII SMP Negeri 1 Bontang.

Keywords: Basic teaching skills of teachers, learning outcomes and junior high school students

\section{PENDAHULUAN}

Akhir - akhir ini, kualitas pendidikan di Indonesia intens diperbincangkan, baik dikalangan praktisi pendidikan, politisi, masyarakat maupun pihak pengambil kebijakan. Kualitas pendidikan nasional dinilai banyak kalangan belum memiliki kualitas yang memadai bila dibandingkan dengan kualitas pendidikan di negara-negara tetangga. Kualitas pendidikan di Indonesia semakin terpuruk bila dibandingkan dengan negara - negara besar lainnya pada abad ke21. Padahal pendidikan menjadi variabel penting dalam proses pencerdasan anak bangsa. Peningkatan mutu pendidikan tidak terlepas dari salah satu komponen yang terpenting yaitu guru. Guru harus mengetahui keadaan dan kemampuan siswa, sehingga 
guru dapat menempatkan dirinya sesuai dengan keadaan siswa tersebut dalam mengajar, sehingga siswa dapat menerima pembelajaran dari guru dengan baik (Rizki, 2016).

Fisika merupakan bagian dari Ilmu Pengetahuan Alam (IPA) yang mempelajari gejala dan peristiwa fenomena alam. Fisika juga merupakan ilmu pengetahuan dasar yang memiliki pengaruh besar terhadap semua ilmu lain karena berhubungan dengan perilaku dan struktur benda, karena itu fisika perlu dipelajari secara mendalam agar semua ilmu pengetahuan dan teknologi menjadi sempurna. Namun kenyataannya, dalam proses pembelajaran fisika terutama dari pihak peserta didik merasa kesulitan dalam memahami konsep-konsep fisika terutama dalam penalarannya serta mengaitkan fisika dengan kehidupan sehari-hari, sampai akhirnya mata pelajaran fisika cenderung diremehkan dan kurang diminati siswa karena ada yang membosankan, pelajaran fisika kurang menarik, dan cenderung membuat siswa gaduh atau mengantuk, sehingga pelajaran fisika tidak dapat berfungsi dengan baik.

Berdasarkan hasil observasi yang dilakukan diketahui bahwa faktor-faktor yang menyebabkan rendahnya hasil belajar siswa pada mata pelajaran Fisika (IPA) pada kelas VIII SMP Negeri 1 Bontang diduga karena masih terdapat kesenjangan pada saat proses pembelajaran yang terjadi, dapat dilihat saat pembelajaran berlangsung siswa diberikan pertanyaan oleh guru dan belum berani dijawab oleh siswa. dan sebaliknya apabila diberikan kesempatan untuk bertanya masih tetap tidak ada siswa yang memanfaatkannya, bahkan ketika ada bagian yang belum mereka pahami merekapun tidak berani mengemukakan pendapatnya.

Namun tidak semua peserta didik beranggapan sama atau pun sependapat karena terdapat juga sebagian peserta didik mengatakan bahwa fisika itu tidak terlalu sulit, karena fisika itu juga sangat erat dalam kehidupan sehari-hari apa lagi ketika guru melakukan suatu percobaan pratikum yang membuat peserta didik merasa ingin tahu. Sehingga timbul rasa ketertarikan yang dilakukan guru tersebut. Oleh karena itu, keterampilan mengajar guru fisika masih harus diperhatikan, terkadang dalam proses pembelajaran fisika di kelas guru masih menggunakan pembelajaran satu arah, penggunaan media pembelajaran masih kurang dan berorientasi pada buku sehingga tidak dapat mengaitkan materi fisika dengan kehidupan sehari-hari, sehingga siswa cenderung kurang perhatian dan mudah merasa bosan, yang berdampak pada pembelajaran fisika hasilnya kurang optimal dan memuaskan.

Beberapa upaya yang dapat dilakukan oleh guru agar kemampuan mengajarnya lebih baik adalah membuat tampilan dan hiasan yang menarik dikelas, pembuatan RPP yang efektif, merancang pembelajaran yang kreatif, pembuatan media sumber belajar, dan paling utama adalah menguasai keterampilan dasar mengajar. Dengan pola pembelajaran yang lebih kreatif dan inovatif peserta didik tidak akan bosan dalam mengikuti Proses Belajar Mengajar (PBM) sehingga peserta didik akan semangat belajar serta lebih fokus, dan menciptakan persepsi positif peserta didik terhadap keterampilan dasar mengajar guru.

Berkenaan dengan keterampilan dasar mengajar, maka yang perlu dipahami bahwa di dalam mengajar adanya pembelajaran, di mana pembelajaran merupakan suatu proses yang kompleks dan melibatkan berbagai aspek yang saling berkaitan. Oleh karena itu, untuk menciptakan pembelajaran yang kreatif dan menyenangkan diperlukan berbagai keterampilan. Keterampilan dasar mengajar adalah kompetensi profesional yang cukup kompleks, sebagai integrasi dari berbagai kompetensi pendidik secara utuh dan menyeluruh. Ada delapan keterampilan mengajar yang sangat berperan dan menentukan kualitas pembelajaran yaitu (1) 
keterampilan bertanya, (2) keterampilan memberi penguatan, (3) keterampilan mengadakan variasi, (4) keterampilan menjelaskan, (5) keterampilan membuka dan menutup pelajaran, (6) keterampilan membimbing diskusi kelompok kecil, (7) keterampilan mengelola kelas serta (8) membelajarkan kelompok kecil dan perorangan (Desnita, 2017).

Untuk itu, perlu dilakukan optimalisasi keterampilan dasar mengajar guru dalam proses pembelajaran agar mendapatkan hasil belajar fisika menjadi lebih baik. Berkaitan dengan hal tersebut, peneliti merasa perlu melakukan penelitian untuk melihat apakah ada pengaruh keterampilan dasar mengajar guru terhadap hasil belajar Fisika (IPA) pada kelas VIII SMP Negeri 1 Bontang.

\section{METODE}

Jenis penelitian ini adalah jenis penelitian kuantitatif dengan metode penelitian yang digunakan yaitu metode survey explanatory. Metode survey explanatory adalah suatu metode penelitian yang mengambil sampel dari suatu populasi dengan menggunakan kuisioner sebagai alat pengumpul data yang utama untuk melihat hubungan antara variabel melalui pengujian hipotesis. Dengan metode yang digunakan maka akan mendapat kejelasan tentang pengaruh keterampilan dasar mengajar guru terhadap hasil belajar siswa pada mata pelajaran fisika di SMP Negeri 1 Bontang.

Populasi dalam penelitian ini adalah seluruh siswa kelas VIII SMP Negeri 1
Bontang. Untuk memperkuat data yang diambil maka teknik pengambilan sampel dalam penelitian ini menggunakan teknik Random Sampling yaitu siswa kelas VIll-A dan VIIl-B yang berjumiah 45 siswa. Variabel dalam penelitian ini meliputi keterampilan dasar mengajar guru $(\mathrm{X})$ dan hasil belajar (Y). Metode pengumpulan data yang digunakan adalah dokumentasi, angket/ kuesioner, dan wawancara. Instrumen yang digunakan adalah lembar rubrik untuk menilai keterampilan dasar mengajar guru. Data yang terkumpul melalui instrumen dianalisis dengan tahapan korelasi terdiri dari tahapan uji prasyarat analisis dan uji hipotesis.

\section{HASIL DAN PEMBAHASAN Analisis Instrumen}

Instrumen yang digunakan dalam penelitian ini telah memenuhi persyaratan dan analisis lebih lanjut mengenai tingkat kesukaran dan daya pembeda instrumen telah terpenuhi. Uji hubungan dan pengaruh dalam penelitian ini akan diuji dengan menggunakan SPSS 20.

\section{Hasil Uji Asumsi Klasik}

Dari analisa uji asumsi klasik diperoleh hasil uji normalitas menyatakan data residual berdistribusi normal, sedangkan hasil uji multikolinieritas menyatakan bahwa data penelitian bebas dari asumsi multikolinearitas. Hasil uji heteroskedastisitas dapat disimpulkan bahwa data yang digunakan tidak terjadi heteroskedastisitas 


\section{Uji Hipotesis}

1. Hasil Analisis Regresi Linier sederhana

Tabel 1

Output Uji Regresi

\begin{tabular}{|c|r|r|r|r|c|}
\hline \multirow{2}{*}{ Model } & \multicolumn{2}{|c|}{$\begin{array}{c}\text { Unstandardized } \\
\text { Coefficients }\end{array}$} & \multicolumn{1}{|c|}{$\begin{array}{c}\text { Standardized } \\
\text { Coefficients }\end{array}$} & & \\
\cline { 2 - 5 } & \multicolumn{1}{|c|}{ B } & Std. Error & \multicolumn{1}{|c|}{ Beta } & \multicolumn{1}{c|}{ T } & Sig. \\
\hline $1 \quad \begin{array}{l}\text { (Constant) } \\
\text { Keterampilan_dasar } \\
\text { mengajar_guru }\end{array}$ & 17.241 & 8.052 & & 2.141 & .038 \\
\hline
\end{tabular}

Dependent Variable: Hasil_belajar

Sumber : data diolah

Tabel di atas menunjukkan persamaan regresi untuk variabel keterampilan dasar mengajar guru dan hasil belajar siswa. Diperoleh persamaan regresi $\mathrm{Y}=17,241+$ $0,778 \mathrm{x}$, artinya setiap penambahan variabel keterampilan dasar mengajar guru sebesar satu satuan maka variabel hasil belajar siswa meningkat sebesar 0,778 satuan.

\section{Uji Determinasi $\left(\mathrm{R}^{2}\right)$}

Tabel 2

Koefisien Korelasi dan Determinasi

\begin{tabular}{|c|c|c|c|c|}
\hline Model & $\mathrm{R}$ & R Square & $\begin{array}{c}\text { Adjusted R } \\
\text { Square }\end{array}$ & Std. Error of the Estimate \\
\hline 1 & $.752^{\mathrm{a}}$ & .566 & .556 & 5.24868 \\
\hline
\end{tabular}

a. Predictors: (Constant), Keterampilan_dasar_mengajar_guru

Sumber : data diolah

b. Dependent variable : Hasil_belajar

Hasil analisis korelasi sederhana dapat dilihat pada output Model Summary dari hasil analisis regresi linier sederhana diatas. Berdasarkan output diperoleh angka $\mathrm{R}$ sebesar 0,752. Karena nilai korelasi sederhana berada diantara 0,60 0,799, maka dapat disimpulkan bahwa terjadi hubungan kuat antara variabel keterampilan dasar mengajar guru (X) terhadap hasil belajar (Y). Nilai R sebesar $0,752=75,20 \%$ dapat dijelaskan bahwa variansi nilai hasil belajar dipengaruhi oleh keterampilan dasar mengajar guru sebesar $\quad 75,20 \%$ sedangkan $\quad 24,80 \%$ dipengaruhi oleh faktor lain. 
Tabel 3

Analisis Varians Uji t

\begin{tabular}{|c|c|c|c|c|c|}
\hline \multirow[b]{2}{*}{ Model } & \multicolumn{2}{|c|}{$\begin{array}{l}\text { Unstandardized } \\
\text { Coefficients }\end{array}$} & $\begin{array}{c}\text { Standardized } \\
\text { Coefficients }\end{array}$ & \multirow[b]{2}{*}{$\mathrm{T}$} & \multirow[b]{2}{*}{ Sig. } \\
\hline & B & Std. Error & Beta & & \\
\hline 1 (Constant) & 17.241 & 8.052 & & 2.141 & .038 \\
\hline $\begin{array}{l}\text { Keterampilan_das } \\
\text { ar_mengajar_guru }\end{array}$ & .778 & .104 & .752 & 7.484 & .000 \\
\hline
\end{tabular}

Dependent Variable: Hasil_belajar

Sumber : data diolah

Berdasarkan pada analisis varians uji t pada tabel 3 didapatkan nilai t hitung $>\mathrm{t}$ tabel $(7,484>2,018)$ maka Ho ditolak, Artinya secara signifikan keterampilan dasar mengajar guru berpengaruh terhadap hasil belajar pada mata pelajaran fisika

\section{Pembahasan}

Tujuan penelitian ini adalah untuk mengetahui pengaruh keterampilan dasar mengajar guru terhadap hasil belajar pada mata pelajaran fisika (IPA) siswa kelas VIII SMP Negeri 1 Bontang. Hasil belajar pada penelitian ini meliputi aspek sikap, aspek pengetahuan dan aspek keterampilan. Hal ini sesuai dengan pembelajaran pada kurikulum 2013 hendaknya dapat mengembangkan pengetahuan, keterampilan dan sikap siswa (Asrizal et,al 2018). Pendapat ini didukung oleh Permendikbud nomor 22 tahun 2016 tentang Standar Penilaian Pendidikan, penilaian hasil belajar siswa pada pendidikan dasar dan pendidikan menengah meliputi aspek sikap, pengetahuan dan keterampilan.

Guru sangat menentukan hasil belajar siswa karena guru merupakan direktur sekaligus aktor dalam proses pembelajaran yang akan mempengaruhi hasil belajar siswa. Selain itu, guru yang secara langsung membimbing, membantu, mempengaruhi, dan mengembangkan potensi yang ada pada siswa mencapai tujuan. Hal tersebut sesuai dengan pendapat (Pasaribu, 2015) yang menyatakan bahwa guru merupakan komponen yang sangat penting dalam proses belajar mengajar karena keberhasilan pelaksanaan proses pendidikan sangat bergantung pada guru. Keterampilan mengajar guru fisika yang baik dapat mendorong siswa untuk lebih mudah memahami dan menerima pelajaran fisika (IPA) sehingga dapat mengembangkan pengetahuan dan teknologi.

Hasil ini membuktikan relevansi teori yang dikemukakan oleh (Uno, 2009) yang menyatakan bahwa pada dasarnya perubahan perilaku yang dapat ditunjukkan oleh siswa pasti dipengaruhi oleh latar belakang pendidikan dan pengalaman yang dimiliki seorang guru. Oleh karena itu, semakin tinggi tingkat keterampilan mengajar guru juga akan berpengaruh pada hasil belajar yang diperoleh siswa.

Guru harus mengetahui keadaan dan kemampuan siswa, sehingga guru dapat menempatkan dirinya sesuai dengan keadaan siswa tersebut dalam mengajar, sehingga siswa dapat menerima pembelajaran dari guru dengan baik (Rizki, 2016). Ambarwati (dalam Yuanita, 2019) menyatakan bahwa guru yang terampil dalam mengajar akan dengan mudah menghadapi siswa yang memiliki latar belakang dan kecerdasan yang bervariasi. Ada delapan keterampilan mengajar yang sangat berperan dan menentukan kualitas 
pembelajaran yaitu (1) keterampilan bertanya, (2) keterampilan memberi penguatan, (3) keterampilan mengadakan variasi, (4) keterampilan menjelaskan, (5) keterampilan membuka dan menutup pelajaran, (6) keterampilan membimbing diskusi kelompok kecil, (7) keterampilan mengelola kelas serta (8) membelajarkan kelompok kecil dan perorangan (Desnita, 2017).

Berdasarkan uji determinasi diperoleh koefisien determinasi $\left(\mathrm{r}^{2}\right)$ pada penelitian ini adalah sebesar 0,752 atau sebesar $75,20 \%$ memberikan informasi yang menjelaskan bahwa sebesar 75,20\% data hasil belajar siswa (variabel y) dipengaruhi oleh keterampilan dasar mengajar guru (variabel x). Artinya baik tidaknya keterampilan dasar mengajar guru secara langsung maupun tidak akan berpengaruh terhadap hasil belajar siswa.

Berdasarkan pada analisis pengujian hipotesis menunjukkan bahwa variabel keterampilan dasar mengajar guru berpengaruh signifikan terhadap hasil belajar siswa pada mata pelajaran fisika siswa kelas VIII SMP Negeri 1 Bontang terbukti hasil uji thitung sebesar 7,484 dan $\mathrm{t}$ tabel sebesar 2,018 pada taraf 5\%. Disini terlihat bahwa hasil $\mathrm{t}$ hitung secara empirik lebih besar dari pada $\mathrm{t}$ tabel $(7,484>2,018)$ maka Ho ditolak. Hal ini menunjukkan bahwa tingkat keterampilan mengajar guru akan berdampak pada perbedaan pencapaian hasil belajar yang diperoleh di sekolah. Jadi dapat disimpulkan bahwa terdapat pengaruh antara keterampilan mengajar guru dengan hasil belajar siswa

\section{KESIMPULAN}

Berdasarkan hasil penelitian dan pembahasan dapat disimpulkan bahwa terdapat pengaruh yang signifikan antara keterampilan dasar mengajar guru terhadap hasil belajar siswa dalam memahami materi cahaya kelas VIII-A dan VIII-B SMP Negeri 1 Bontang. Semakin tinggi keterampilan dasar mengajar guru, semakin tinggi pula hasil belajar siswa, begitu juga sebaliknya semakin rendah keterampilan dasar mengajar guru, semakin rendah pula hasil belajar siswa. Sehingga dalam proses pembelajaran secara real di kelas, guru tidak hanya menguasai pengetahuan, tetapi keterampilan dalam mengajarkan siswa perlu diutamakan. Seperti yang dikatakan oleh Suparman (2010:59) bahwa "syarat mutlak untuk efektifnya sebuah proses pembelajaran adalah keterampilan mengajar seorang guru". Dengan begitu, dapat dikatakan hipotesis dalam penelitian ini diterima

\section{REFERENSI}

Ambarwati, M. (2016). Analisis keterampilan mengajar calon guru pendidikan matematika pada mata kuliah Microteaching. Jurnal Pedagogia, 5(1), 81-90.

Asrizal, A., Amran, A., Ananda, A., Festiyed, F., \& Sumarmin, R. (2018). The development of integrated science instructional materials to improve students' digital literacy in scientific approach. Jurnal Pendidikan IPA Indonesia, 7(4), 442-450.

Desnita, D., \& Susanti, D. (2017). Science Process Skills-Based Integrated Instructional Materials to Improve Student Competence Physics Education Prepares Learning Plans on Teaching Skills Lectures. Jurnal Penelitian \& Pengembangan Pendidikan Fisika, 3(1), 35-42.

Djamarah, S. B. (2010). Guru dan Siswa dalam Interaksi Edukatif. Jakarta : Rineka Cipta.

Pasaribu, E. (2015). Meningkatkan Hasil Belajar dengan Metode Contextual Teaching Learning pada Mata Pelajaran Sejarah. Jurnal Pendidikan Ilmu-Ilmu Sosial, 7(1), 13-19.

Rizki, MY (2016). Peningkatan Keterampilan Memberi Umpan Balik Guru Pendidikan Jasmani dan Kesehatan Kecamatan 
Taman Kabupaten Sidoarjo. Jurnal SPORTIF: Jurnal Penelitian Pembelajaran, 2(1), 72. https://doi.org/10.29407/js_unpgri.v2i1. 658

Samudra, G. B., Suastra, I. W., \& Suma, K. (2014). Permasalahan-Permasalahan yang Dihadapi Siswa SMA di Kota Singaraja dalam Mempelajari Fisika. Jurnal Program Pascasarjana Universitas Pendidikan Ganesha Program Studi IPA. 4.

Sigala, L. (2016). Hubungan Persepsi Siswa tentang Cara Mengajar Guru dengan Motivasi Belajar Siswa yang Pernah Mengikuti Remedial Kimia di SMA ITCI Penajam Paser Utara (Khusus Siswa-Siswi Ilmu Pengetahuan Alam). Jurnal Psikoborneo. 4 (3). 462-469

Sophuan, S. (2018). Peningkatkan Keterampilan Mengajar Guru SMP mata Pelajaran IPA Dalam Menerapkan Pendekatan Saintifik. Tadrib: Jurnal
Pendidikan Agama Islam, 4(2), 335-355. https://doi.org/10.19109/tadrib.v4i2.2860

Sugiyono. (2015). Metodologi Penelitian Kuantitatif Kualitatif R\&D. Bandung: Alfabeta.

Sukardi (2004). Metodologi Penelitian Pendidikan. Jakarta: Bumi Aksara

Suparman, S. (2010). Gaya Mengajar yang Menyenangkan Siswa. Yogyakarta: Pinus Book Publisher.

Uno, HB 2009. Profesi Kependidikan. Jakarta: PT.Bumi Aksara

Yuanita, Y. (2019). Tingkat Keterampilan Dasar Mengajar Calon Guru Sekolah Dasar Pada Perkuliahan Mikroteaching [Tingkat Keterampilan Dasar Mengajar Calon Guru Sekolah Dasar di Kuliah Mikroteaching]. PEDAGOGIA: Jurnal Pendidikan, $8(1)$. https://doi.org/10.21070/pedagogia.v8i1 .1952 